\title{
PEMBERDAYAAN KELOMPOK WANITA TANI MELALUI PERINTISAN USAHA MIKRO YOGHURT SUSU KAMBING
}

\author{
Meilan Sugiarto', Darban Haryanto², Ida Susi Dewanti3 \\ 123Universitas Pembangunan Nasional Veteran Yogyakarta \\ 1Email address meilan.sugiarto@upnyk.ac.id ; ${ }^{2}$ Email address \\ darbanharyanto@ymail.com; \\ 3 Email address idasusidewanti@yahoo.com
}

\begin{abstract}
The rationale of this community service program is farmer women groups empowerment of Hunian Tetap Gondang 3 Wukirsari Sleman throught pioneering goat milk yoghurt micro business, so the purpose of this community dedication program is to innovate through IPTEKS transfer by making goat milk yoghurt, which will be a stimulus for the emergence of micro business. The method which used in these program was mentoring, training, procurement tools, and technical guidance to the partner groups. Based on the implementation result, there is increasing sale value of goat milk after processed into yoghurt and the synergy between two groups of community dedication program partners have been well established, as well as increased knowledge and skills for packaging, micro business finance management, and entrepreneurship. There was availability of production room for the group to continuous produce, therefore, at the end of this program production and sales have running despite receiving orders from the closest colleagues and participation in the bazaar or exhibition.
\end{abstract}

Keywords: community service, empowerment, goat milk yoghurt, micro business

\begin{abstract}
Abstrak
Dasar pemikiran program pengabdian masyarakat ini adalah pemberdayaan kelompok wanita tani Hunian Tetap Gondang 3 Wukirsari Sleman melalui rintisan usaha mikro yoghurt susu kambing, tujuannya adalah melakukan inovasi melalui transfer IPTEKS melalui pembuatan yoghurt susu kambing yang diharapkan menjadi rangsangan munculnya bisnis mikro. Metode yang digunakan adalah pendampingan, pelatihan, pengadaan alat, dan bimbingan teknis bagi kelompok mitra. Berdasarkan hasil implementasi terjadi peningkatan nilai jual susu kambing setelah diolah menjadi yoghurt dan terjalin sinergi antara kelompok mitra serta peningkatan pengetahuan dan keterampilan pengemasan, pengelolaan keuangan usaha mikro, dan kewirausahaan. Untuk kelanjutannya, telah disediakan ruang produksi bagi kelompok mitra, dimana diakhir program ini produksi dan penjualan produk telah berjalan walaupun baru pada tingkat pesanan dari rekan terdekat dan mengikuti bazar atau pameran.
\end{abstract}


Kata Kunci: pengabdian masyarakat, pemberdayaan, yoghurt susu kambing, bisnis mikro

\section{PENDAHULUAN}

Hunian Tetap (Huntap) Gondang 3 Desa Wukirsari Kecamatan Cangkringan Kabupaten Sleman merupakan salah satu hunian yang dibangun pemerintah daerah untuk menampung para pengungsi erupsi Merapi di tahun 2010. Pembangunan hunian tetap tersebut merupakan suatu program rehabilitasi dan rekonstruksi yang dilakukan oleh pemerintah daerah dalam menangani pasca erupsi Gunung Merapi (https://jogjaprov.go.id).

Kondisi sosial ekonomi kehidupan masyarakat pasca erupsi Gunung Merapi berubah drastis, sebelumnya para warga tinggal di sebuah lingkungan pedesaan dengan halaman rumah yang luas dan lingkungan yang masih alami dengan pekerjaan tetap sebagai petani maupun peternak. Namun sekarang para warga merasakan keterbatasan dalam beraktivitas karena lahan pertanian maupun peternakan sudah rusak dan jauh dari permukiman yang ditempati sekarang. Tingginya ketergantungan keluarga pada satu sumber pendapatan ditambah kebutuhan yang semakin hari semakin meningkat dan jika tidak diimbangi dengan tingkat daya beli keluarga yang sesuai, maka kemandirian dan tingkat kesejahteraan akan mengalami gangguan yang pada akhirnya lambat laun program rehabilitasi dan rekonstruksi yang dilakukan oleh pemerintah daerah selama ini akan kembali menghadapi hambatan.

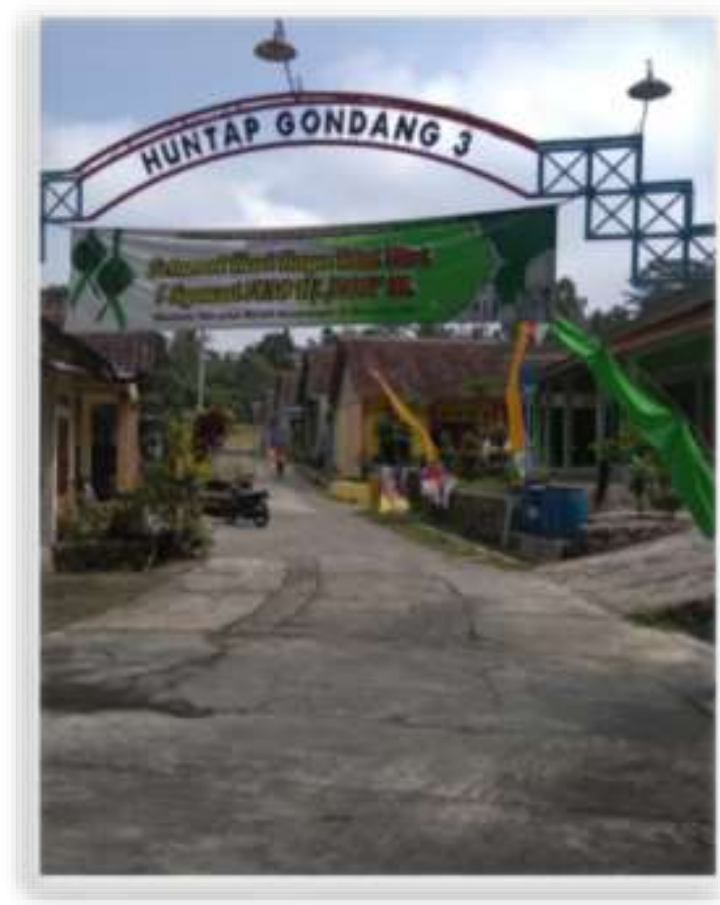

Gambar 1. Gerbang masuk huntap gondang 3 desa wukirsari

Sumber: dok tim pelaksana IbM, 2016.

Kegiatan pengabdian masyarakat ini merupakan program Iptek bagi Masyarakat (IbM) yang dalam pelaksanaannya bekerjasama dengan dua mitra di Huntap Gondang 3 Desa Wukirsari, Cangkringan, Sleman. 
Kelompok wanita tani "Adem Ayem" merupakan mitra pertama, Ibu Warsiyem atau lebih akrab disapa Ibu Mawar adalah ketua kelompok tersebut. Mewakili kelompoknya, Ibu Mawar menjelaskan bahwa kelompoknya memiliki semangat dan keinginan berwirausaha yang tinggi, namun selama ini aktivitas ibu-ibu dalam kelompok tersebut belum dapat menunjukkan aktivitas yang bernilai ekonomis untuk membantu menambah pendapatan keluarga. Kondisi ini terjadi karena adanya hambatan yang dirasakan yaitu masih terbatasnya pengetahuan dan ketrampilan untuk mengembangkan potensi yang ada di lingkungan Huntap Gondang 3 Desa Wukirsari.

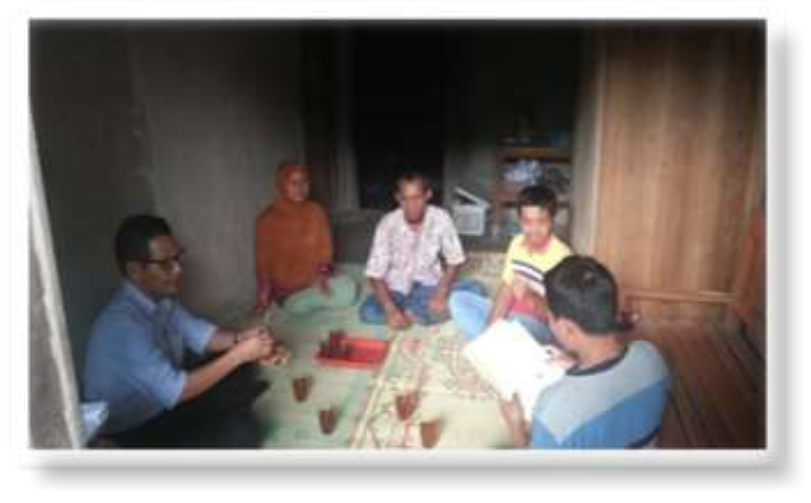

Gambar 2. Diskusi tim pelaksana dengan mitra untuk mengidentifikasi potensi dan persoalan yang dihadapi mitra Sumber: dok tim pelaksana IbM, 2016.

Mengacu pada harapan dan keterbatasan kelompok wanita tani “Adem Ayem” Huntap Gondang 3 tersebut, maka pemberdayaan perlu dilakukan untuk menumbuhkan jiwa wirausaha mandiri dengan mengelola potensi yang ada di lingkungan sekitar, sehingga pada akhirnya mampu menambah penghasilan menuju kesejahteraan keluarga untuk hidup layak (Shane, Edwin, \& Christoper, 2003). Daulay (2006) juga menegaskan bahwa metode pemberdayaan merupakan salah satu pendekatan pembangunan dalam proses penguatan ekonomi dan sosial untuk meningkatkan kesejahteraan hidup masyarakat.

Kelompok peternak kambing "Sido Makmur" Huntap Gondang 3 adalah mitra kedua dari kegiatan ini. Kelompok tersebut diketuai oleh Bapak Burhanudin. Informasi yang diperoleh dari kelompok tersebut, sampai saat ini susu kambing yang dihasilkan masih dijual dalam bentuk cair, dijual dalam kemasan plastik 200ml dengan harga eceran Rp10.000-Rp15.000 per-liter. Pemasarannya hanya mengandalkan permintaan masyarakat sekitar belum dipasarkan secara umum. Kelompok peternak kambing Huntap Gondang 3 sedang berusaha meningkatkan produktivitas kambing perah, namun adanya keterbatasan maka penambahan kuantitas tidak akan berpengaruh pada penghasilan karena susu yang dihasilkan masih dijual dalam bentuk susu cair saja, sehingga dinilai kurang optimal. 
Peternakan kambing merupakan kegiatan ekonomi yang diandalkan oleh komunitas warga Huntap Gondang 3 Desa Wukirsari Sleman. Penanganan kambing potong selama ini sudah baik tidak ada masalah yang berarti, namun yang masih membutuhkan perhatian dan solusi adalah kambing perah yaitu output yang dihasilkan (susu kambing) dapat diolah menjadi produk dalam bentuk lain dan lebih mudah dipasarkan, mengingat pemasaran dan penjualan susu kambing tidak semudah susu sapi. Hal ini merupakan tantangan, walaupun pemasaran produk merupakan problem lama dari sebuah hasil produksi yang berlaku bagi hampir semua produk. Ditinjau dari sudut pandang pemasaran, seorang pemasar pada dasarnya dituntut memahami permasalahan pokok di bidangnya yang selanjutnya perlu disusun strategi agar dapat mencapai tujuannya (Sunyoto, 2012).

Setelah melakukan analisis situasi, baik melalui diskusi dengan mitra maupun observasi awal di lokasi, maka diperoleh informasi tentang potensi di Huntap Gondang 3 Desa Wukirsari. Potensi tersebut dapat dibagi menjadi dua aspek yaitu aspek produksi, antara lain: tersedianya susu kambing dari kelompok peternak; adanya tempat yang dimliki kelompok wanita tani "Adem
Ayem" Huntap Gondang 3 yang dapat digunakan untuk mengolah susu kambing menjadi produk lain yang bernilai ekonomis; rencana tambahan ternak kambing perah kelompok peternak kambing "Sido Makmur" Huntap Gondang 3 untuk mengoptimalkan kandang. Potensi berikutnya adalah aspek manajemen usaha yang mencakup semangat dan keinginan mitra untuk berwirausaha dan masih terbukanya pasar untuk produk olahan susu kambing.

Di sisi lain, hasil analisis situasi menunjukkan adanya permasalahan yang dihadapi mitra dari aspek produksi yaitu belum memiliki kemampuan dan ketrampilan mengolah susu kambing menjadi produk lain; belum memiliki peralatan pendukungnya; belum memiliki ketrampilan dan pengetahuan tentang pengemasan produk; belum termanfaatkannya tempat kelompok wanita tani "Adem Ayem" Huntap Gondang 3 secara optimal untuk kegiatan berdampak ekonomis; adanya kebutuhan pengetahuan tentang peningkatan kualitas susu kambing. Sedangkan dari sisi manajemen usaha adalah belum memiliki pengetahuan dan ketrampilan yang cukup baik untuk menjadi wirausaha di sektor usaha mikro; belum memiliki pengetahuan 
tentang administrasi usaha mikro; dan belum memiliki keterampilan dan pengetahuan tentang kemasan dan pelabelan produk. Oleh karena itu, melalui kegiatan pengabdian masyarakat ini berupaya memecahkan permasalahan yang dihadapi tersebut.

Tujuan kegiatan pengabdian masyarakat melalui program IbM ini secara umum adalah menciptakan sinergi antara kelompok wanita tani "Adem Ayem" dengan kelompok peternak kambing "Sido Makmur" Huntap Gondang 3 Desa Wukirsari Kabupaten Sleman yang diarahkan untuk memecahkan permasalahan yang dihadapi dengan memanfaatkan sumber daya yang dimiliki mitra. Sedangkan tujuan lain dari kegiatan ini adalah menerapkan inovasi melalui transfer IPTEK berupa pembuatan yoghurt berbahan dasar susu kambing yang diharapkan menjadi stimulus untuk perintisan embrio usaha mikro kelompok wanita tani "Adem Ayem".

Selain itu, kegiatan ini merupakan bentuk pemberdayaan perempuan yang dinilai sangat penting untuk dapat menjawab berbagai tantangan serta memanfaatkan peluang di masa yang akan datang. Para ibu rumah tangga yang tergabung dalam kelompok wanita tani "Adem Ayem" akan berkesempatan membantu pendapatan keluarganya melalui wirausaha kelompok namun tidak meninggalkan tugas utama sebagai ibu rumah tangga mengurus anak dan rumah mereka. Nantinya, melalui usaha mikro yang dikelola bersama oleh kelompok wanita tani tersebut akan menjadikan para ibu rumah tangga memiliki potensi sebagai motor penggerak pemberdayaan ekonomi keluarga melalui kegiatan usaha ekonomi produktif.

\section{METODE DAN PELAKSANAAN}

Kelompok masyarakat sasaran adalah kelompok wanita tani dan kelompok peternak kambing Huntap Gondang 3 Desa Wukirsari Kabupaten Sleman. Metode pelaksanaan kegiatan adalah pendampingan, pelatihan, pengadaan alat, bimbingan teknis dalam bentuk praktek bersama dan evaluasi kegiatan. Pendampingan dilakukan tim pelaksana dibantu mahasiswa dalam perintisan usaha mikro kelompok wanita tani dan penanganan administrasi usaha. Sedangkan untuk pelatihan pembuatan yoghurt susu kambing dilakukan dengan mengundang instruktur yang ahli dalam pengolahan susu kambing dan dilaksanakan dengan model praktis berupa bimbingan teknik dengan demonstrasi langsung dan mitra 
dilibatkan langsung dalam praktek agar saat produksi sudah dapat dilakukan mandiri, begitu pula untuk pengelolaan kambing perah menggunakan metode yang sama. Pelatihan pengemasan dan pelabelan produk dipandu oleh tim pelaksana dibantu mahasiswa yang dilaksanakan dalam bentuk bimbingan teknis dan praktek langsung pengemasan dan pelabelan produk yang dihasilkan mitra. Tim pelaksana dibantu mahasiswa juga memberikan pelatihan dasar tentang kewirausahaan bagi mitra. Untuk mendukung mitra mewujudkan hasil pelatihan dan pendampingan yang diikutinya, tim pelaksana dibantu mahasiswa melakukan pengadaan peralatan maupun material yang dibutuhkan mitra seperti peralatan pengolahan susu kambing menjadi yoghurt, kemasan, pelabelan, fasilitasi ruang produksi.

Selanjutnya, untuk mengetahui hasil pelaksanaan kegiatan pendampingan maupun pelatihan tersebut dilakukan evaluasi secara internal dan eksternal, secara internal dilakukan tim pelaksana setiap akhir sesi setelah kegiatan tersebut dieksekusi dengan melibatkan mitra. Secara kelembagaan, tim pelaksana juga membuat progress dan final report pelaksanaan kegiatan pengabdian masyarakat ini yang kemudian dimonitoring dan dievaluasi oleh pihak LP2M Universitas Pembangunan Nasional Veteran Yogyakarta. Kegiatan IbM ini didanai oleh Kementerian Riset, Teknologi, dan Pendidikan Tinggi Republik Indonesia, sehingga evaluasi eksternal dilakukan oleh perwakilan dari kementerian tersebut melalui kegiatan monitoring dan evaluasi terhadap kemajuan kegiatan maupun hasil dan luaran dari kegiatan ini.

\section{HASIL DAN PEMBAHASAN}

Kegiatan ini telah dilaksanakan sesuai skedul yang direncanakan dan berbagai capaian yang telah diperoleh dari kegiatan ini sebagai berikut:

\section{Pelatihan Dan Pendampingan Pembuatan Yoghurt Susu Kambing}

Antiseptik alami terkandung dalam susu kambing, antiseptik tersebut bisa membantu menekan pengembangan bakteri dalam tubuh. Susu kambing disinyalir tidak menyebabkan sembelit bagi orang yang meminumnya karena kandungan protein yang lembut dan dampak laksatif yang ringan (Moeljanto et al., 2002). Bahkan, susu kambing juga dianjurkan dikonsumsi untuk pertumbuhan bayi, ibu hamil, menyusui, orang tua, sampai untuk penyembuhan berbagai penyakit serta kecantikan kulit 
(Mulyadi, 2015). Dengan demikian, susu kambing dinilai sangat bermanfaat bagi orang yang mengkonsumsinya. Melalui pengolahan susu kambing menjadi yoghurt (Sirait, 1984) akan meningkatkan minat masyarakat untuk mengkonsumsi susu kambing dibandingkan dalam bentuk susu kambing murni.

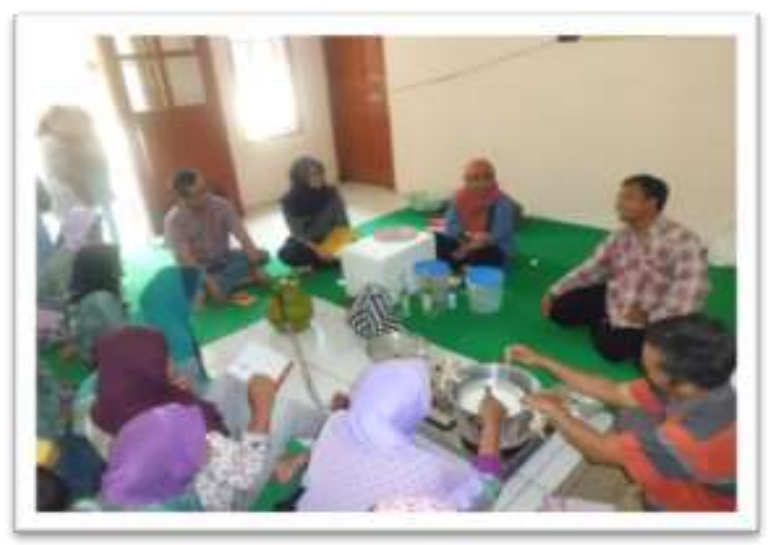

Gambar 3. Kegiatan pelatihan pembuatan yoghurt susu kambing Sumber: dok tim pelaksana IbM, 2016.

Transfer pengetahuan dan ketrampilan dalam pengolahan susu kambing menjadi yoghurt susu kambing telah dilakukan oleh tim pelaksana melalui pemberian pelatihan kepada mitra dengan mengundang instruktur yang ahli di bidangnya. Kegiatan tersebut merupakan implementasi inovasi produk melalui transfer IPTEK bagi mitra untuk dapat melakukan inovasi pada susu kambing agar mampu meningkatkan nilai jual melalui varian produk berbahan dasar susu kambing.

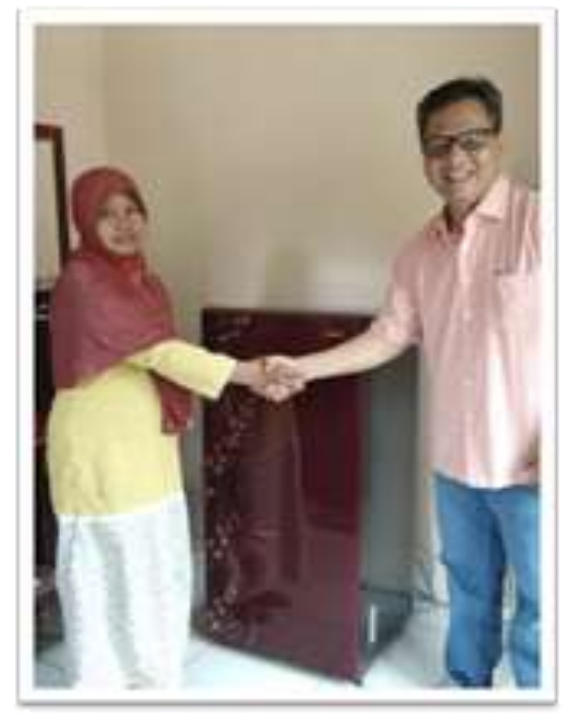

Gambar 4. Stimulan berupa peralatan dan renovasi ruangan produksi dari tim IbM kepada mitra

Sumber: dok tim pelaksana IbM, 2016.

Pelatihan dilaksanakan dalam bentuk bimbingan teknis dengan demonstrasi langsung dan mendampingi mitra untuk praktek langsung. Para anggota kelompok wanita tani "Adem Ayem" sebagai peserta belajar dan didampingi untuk praktek langsung dalam pembuatan yoghurt berbahan dasar susu kambing. Luaran dari kegiatan pelatihan ini, kelompok wanita tani tersebut memahami dengan baik proses pengolahan susu kambing menjadi yoghurt dan telah mampu membuat yoghurt berbahan dasar susu kambing. Pada akhir kegiatan pengabdian masyarakat ini tim pelaksana dibantu mahasiswa melakukan evaluasi, dimana hasilnya menunjukkan kelompok wanita tani "Adem Ayem" telah memiliki kemampuan dan ketrampilan mengolah 
susu kambing menjadi yoghurt dan sudah menerima beberapa pesanan.

\section{Pelatihan Dan Pendampingan Pengemasan dan Pelabelan Produk Yoghurt Susu Kambing}

Ditinjau dari segi pemasaran, produk susu kambing masih relatif menghadapi batasan karena masih dianggap sebagai produk yang aneh dibenak konsumen. Inovasi dan kreatifitas dibutuhkan, baik dalam pengolahan maupun teknik pemasarannya agar produk susu kambing mudah diterima di berbagai kalangan konsumen mengingat muatan nutrisinya sangat bermanfaat bagi kesehatan, bahkan dianggap hampir sama dengan ASI (Safitri, 2012).

Pengemasan adalah aktivitas mendesain dan membuat kemasan atau tempat suatu produk. Kemasan dinilai esensial bagi produk karena tidak hanya sebagai protektor bagi produk, namun dapat juga berperan sebagai media promosi untuk menarik konsumen, sehingga memutuskan untuk membeli produk yang ditawarkan (Kotler, 2010). Selain kemasan, pemberian label yang merupakan satu kesatuan dalam kemasan juga perlu diperhatikan. Label merupakan suatu tempelan sederhana atau dapat pula sebuah gambar yang dirancang dengan rumit yang melekat pada suatu produk (Kotler, 2010).
Beberapa produk ada pula yang hanya mencantumkan merek atau mencantumkan banyak informasi dalam label produknya. Pada dasarnya, label memiliki fungsi sebagai identitas produk dan merek, serta dapat menentukan kategori produk, bahkan juga menjadi media promosi dengan mencantumkan gambar yang menarik dalam label.

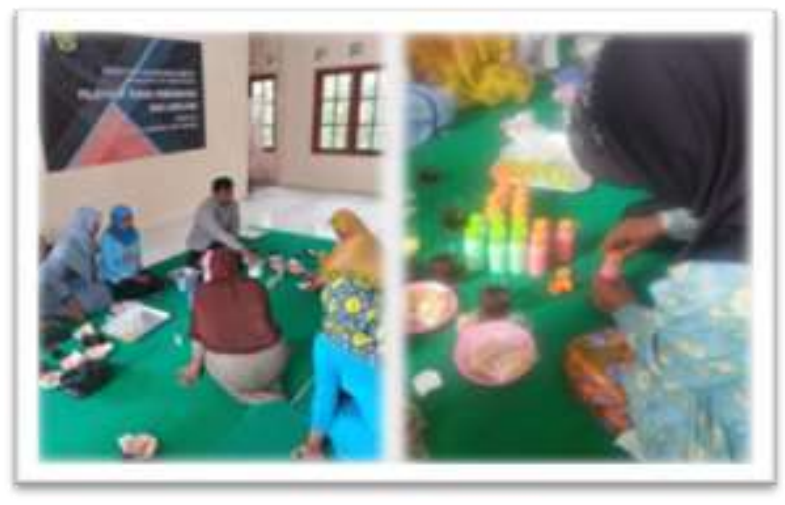

Gambar 5. Kegiatan pelatihan pengemasan dan pelabelan Sumber: dok tim pelaksana IbM, 2016.

Transfer pengetahuan dan ketrampilan berkaitan dengan kemasan dan pelabelan produk yoghurt susu kambing dipandu langsung oleh tim pelaksana dengan dibantu mahasiswa melalui pemberian pelatihan kepada mitra. Pelatihan dilaksanakan dalam bentuk bimbingan teknis dengan demonstrasi langsung dan mendampingi mitra untuk praktek langsung.

Para anggota kelompok wanita tani “Adem Ayem” sebagai peserta belajar dan praktek langsung dalam pengemasan dan pelabelan terhadap 
produk yoghurt susu kambing yang diproduksinya dalam kemasan 100ml dan 200ml. Selain itu, diskusi juga dilakukan dalam berkaitan tentang pemasaran produk. Luaran dari hasil pelatihan ini, kelompok wanita tani sudah mampu mengemas dan memberi label produknya dan memahami cara memasarkan produk. Label yang diberikan oleh kelompok wanita tani pada produk yoghurt hasil produksi mereka dalah HG3 yang merupakan singkatan dari Hunian tetap Gondang

3. Hasil evaluasi yang dilakukan tim pelaksana dan mahasiswa di akhir kegiatan pengabdian masyarakat ini menunjukkan kelompok wanita tani "Adem Ayem" sudah mampu mengemas dan menempelkan label yang telah disepakati kelompok terhadap produknya dengan baik. Pemasaran sudah dilakukan dengan baik, pesanan sudah mulai diterima dan yoghurt hasil kelompok wanita tani tersebut sudah ikut dalam kegiatan bazar desa maupun pameran umum.

Hal yang menarik berkaitan dengan pemasaran yoghurt hasil produksi kelompok wanita tani "Adem Ayem" yaitu adanya respon positif dari Kepala Dukuh (Bapak Toto) maupun Kepala Desa Wukirsari Sleman yang ikut mendukung pemasaran produk tersebut. Yoghurt
HG3 hasil olahan kelompok wanita tani "Adem Ayem" diikutkan dalam bazar desa di Balai Desa Wukirsari dan juga dalam Pameran Komunitas Indonesia yang diadakan di pasar Beringharjo.
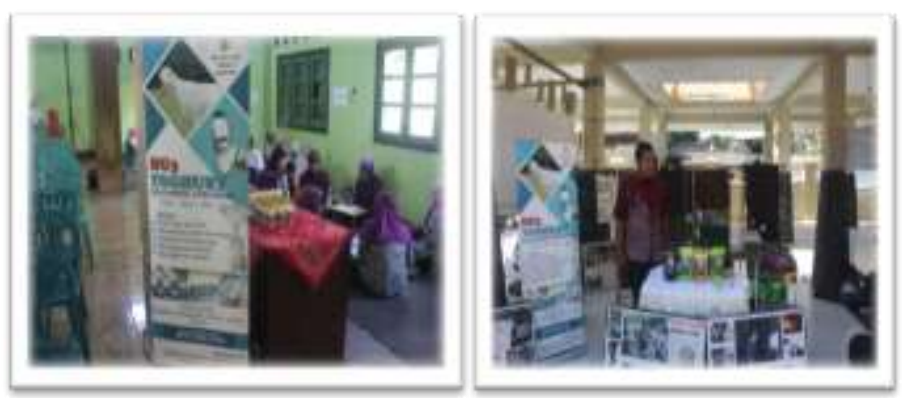

Gambar 6. Promosi yoghurt HG3 karya kelompok wanita tani "Adem Ayem" di Bazar Desa Wukirsari dan Pameran Komunitas Indonesia di Pasar Beringharjo Yogyakarta Sumber: dok tim pelaksana IbM, 2016.

\section{Pelatihan Cara Pengelolaan Kambing Perah Untuk Meningkatkan Kuantitas Dan Kualitas Susu Kambing}

Susu kambing merupakan minuman dengan kandungan nutrisi yang tinggi dan dikenal juga sebagai obat dengan harga yang lebih tinggi dibandingkan susu sapi. Harga yang tinggi dan besarnya manfaat susu kambing, maka tuntutan kualitas susu kambing menjadi meningkat, baik terhadap peternak maupun produsennya (Safitri, 2012).

Transfer pengetahuan dan ketrampilan berkaitan peningkatan kuantitas dan kualitas susu kambing dipandu langsung oleh instruktur yang merupakan praktisi yang diundang oleh 
tim pelaksana untuk memberikan pelatihan berkaitan dengan hal tersebut. Pelatihan dilaksanakan dalam bentuk bimbingan teknis dengan demonstrasi maupun simulasi langsung dan mendampingi mitra yaitu kelompok peternak "Sido Makmur" untuk praktek langsung bagaimana cara memilih bibit kambing perah yang baik, ciri kambing sehat, bentuk ambing kambing perah yang dapat menghasilkan kuantitas susu banyak, pakan yang baik untuk merangsang produksi susu, cara membersihkan kandang. Luaran hasil pelatihan ini adalah para peternak kambing perah memahami dan mempraktekan dengan baik hasil pelatihan dalam upaya meningkatkan kuantitas dan kualitas susu kambing perah yang mereka pelihara. Hasil evaluasi di akhir kegiatan pengabdian masyarakat menunjukkan adanya peningkatan kuantitas susu kambing yang dihasilkan kambing perah yang dipelihara oleh kelompok peternak "Sido Makmur" Huntap Gondang 3.

\section{Pelatihan Dasar Kewirausahaan Dan Pendampingan Administrasi Usaha}

Wirausaha merupakan individu yang memiliki kemampuan untuk menciptakan sesuatu, mandiri, dan berani mengambil risiko melalui pemanfaatan peluang yang ada (Casson et al., 2006). Terkadang tren munculnya wirausaha disebabkan adanya tekanan ekonomi yang mendorong seorang individu memaksakan diri untuk menciptakan lapangan kerja secara mandiri (Bosma, Wennekers, \& Amorós, 2011). Oleh karena itu, untuk menjadi seorang wirausaha dibutuhkan dasar kewirausahaan, dimana salah satu tujuan pengabdian masyarakat ini adalah merintis embrio usaha mikro bagi mitra. Ditegaskan pula bahwa salah satu faktor yang dapat menghambat keberhasilan usaha adalah kurangnya kemampuan manajerial (Riyanti, 2003).

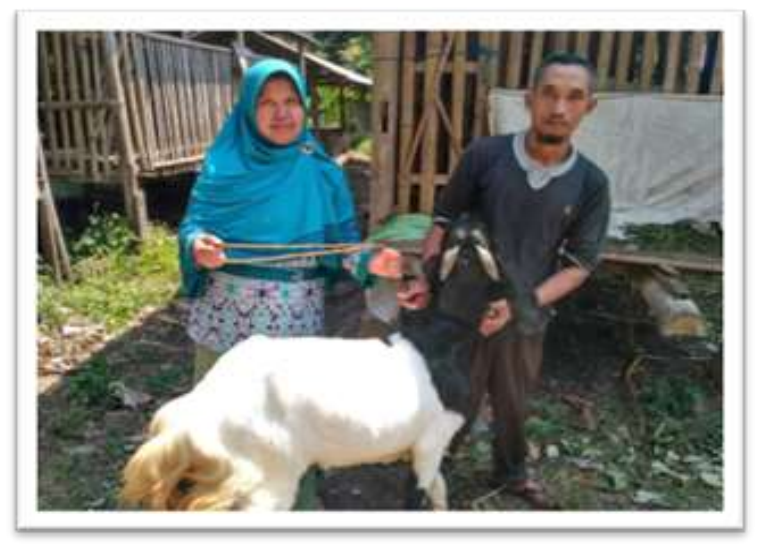

Gambar 7. Stimulan berupa kambing etawa dari tim IbM untuk mitra

Usaha mikro yang dimaksudkan adalah sebuah bentuk usaha bersama (Tampubolon et al., 2006). Manfaat perintisan usaha mikro tersebut didasari pemikiran bahwa usaha mikro adalah salah satu teknik kewirausahaan untuk mempromosikan ekonomi swasembada yang memungkinkan pelaku usaha mikro 
dapat menciptakan lapangan kerja sendiri dan memiliki pendapatan dengan menggunakan metode bottom-up (Fugate et al., 2005).

Transfer pengetahuan dan ketrampilan berkaitan dengan dasar kewirausahaan maupun administrasi usaha dilakukan oleh tim pelaksana dibantu mahasiswa dengan memberikan pelatihan tentang dasar kewirausahaan dan pendampingan administrasi usaha bagi kedua mitra. Pelatihan dilakukan dengan cara melaksana bimbingan teknis dan simulasi sederhana melibatkan setiap anggota kelompok mitra. Luaran hasil pelatihan dan pendampingan yang telah dilakukan adalah para mitra memahami dengan baik dasar-dasar kewirausahaan dan siap menjadi wirausaha yang handal untuk menjalankan usaha skala mikro. Di bidang administrasi usaha, khususnya administrasi keuangan telah dilaksanakan dalam bentuk pencatatan pengeluaran maupun pemasukkan yang sudah mulai terdokumentasikan dengan baik.

\section{Proyeksi Perhitungan Nilai Ekonomis Yoghurt Susu Kambing}

Inovasi melalui transfer IPTEK terhadap susu kambing yang diolah menjadi yoghurt memberikan dampak ekonomis yang nyata (Hermawati,
Kusnandar, \& Setyowati, 2013). Berikut ini merupakan proyeksi perhitungan nilai ekonomis yoghurt susu kambing HG3 produksi kelompok wanita tani "Adem Ayem":

Tabel 1. Proyeksi perhitungan nilai ekonomis yoghurt susu kambing $\mathrm{HG}_{3}$ produksi kelompok wanita tani "Adem Ayem"

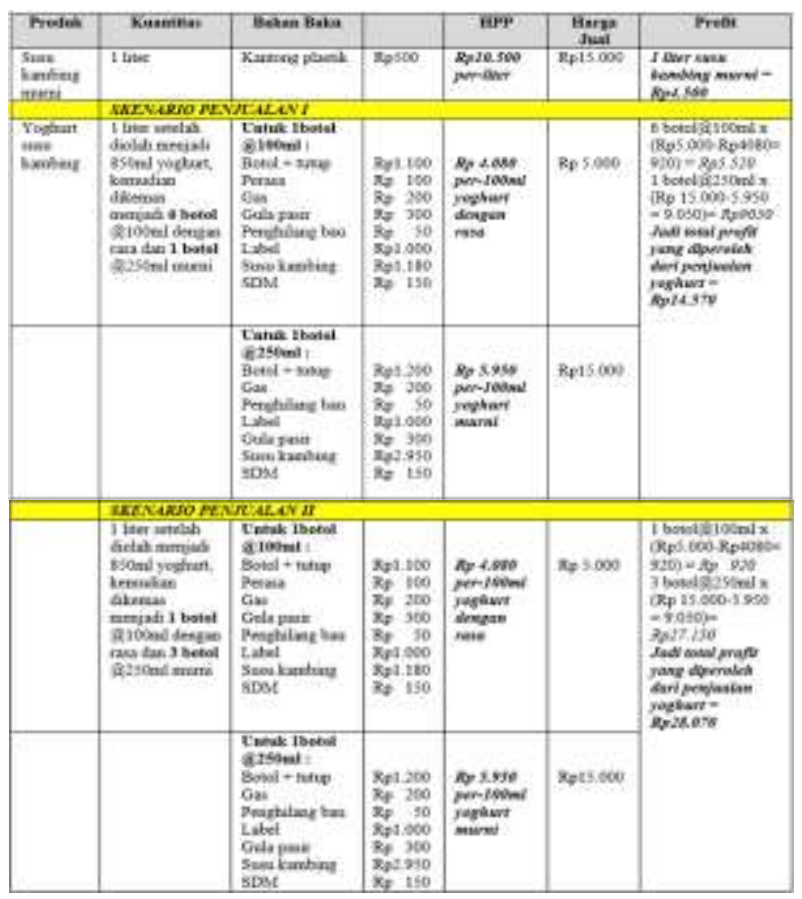

\section{Catatan:}

Proporsi kuantitas yoghurt rasa dengan murni akan mempengaruhi jumlah pendapatan

Evaluasi per semester setelah pelaksanaan tetap dilakukan terhadap perkembangan kedua kelompok mitra di Huntap Gondang 3 Desa Wukirsari untuk memantau keberlanjutannya. Sampai saat ini dengan empat semester berjalan, kelompok wanita tani "Adem Ayem" mampu menjaga keberlanjutan 
atas apa yang pernah didapatkan melalui program IbM ini.

\section{PENUTUP}

Berdasarkan kegiatan pengabdian masyarakat dengan mitra kelompok wanita tani dan kelompok peternak kambing Hunian Tetap Gondang 3 Desa Wukirsari Kabupaten Sleman yang telah dilaksanakan melalui program IbM dengan dana hibah dari Kementerian Riset, Teknologi, dan Pendidikan Tinggi Republik Indonesia dapat disimpulkan:

1. Ditinjau dari aspek produksi, melalui pemberian pelatihan, pendampingan dan bimbingan teknis terhadap mitra menunjukkan luaran yang baik, dimana mitra memperoleh peningkatan kemampuan dan ketrampilan dalam berbagai hal seperti pembuatan yoghurt berbahan dasat susu kambing, pengemasan dan pelabelan produk, meningkatkan produktivitas kambing perah. Sedangkan dari aspek manajemen usaha, mitra sebagai wirausahawan telah memahami dengan baik dan mampu menerapkan manajemen usaha melalui administrasi usaha mikro yang terdokumentasi baik.

2. Dukungan perangkat desa maupun kepala desa sangat membantu dalam mengembangkan hasil karya kelompok mitra di masa datang, terutama dalam memasarkan produk hasil olahan susu kambing ke pihak eksternal. Dengan demikian, kontinyuitas usaha mikro yang dirintis tim pelaksana bersama mitra dapat terjaga dan semakin berkembang.

3. Inovasi yang dilakukan melalui transfer IPTEK dengan mengolah susu kambing menjadi yoghurt telah memberikan dampak ekonomis secara nyata.

\section{Ucapan Terima Kasih}

Terima kasih kepada DP2M Kemenristekdikti Republik Indonesia yang telah mendanai kegiatan pengabdian masyarakat ini melalui skema IbM di tahun anggaran 2016.

\section{DAFTAR PUSTAKA}

Bosma, N., Wennekers S., \& Amorós J.E. 2011. Extended Report: Entrepreneurs and Entrepreneurial Employees Across the Globe. London (GB): Global Entrepreneurship Research Association.

Casson, M., Yeung, B., Basu, A., \& Wadeson, N. 2006. The Oxford Handbook of Entrepreneurship. New York : Oxford University Press Inc. 
Daulay, H. 2006. Pemberdayaan Perempuan : Studi Kasus Pedagang Jamu Di Gedung Johor Medan, Jurnal Harmoni Sosial, 1 (1): 7-14. Fugate, D., Kirk, C., Heriot, \& Raja, B. 2005. Microenterprises in the Kingdom of Nepal: On the Path to Economic Development. Journal of Business.

Harmawati, M., Kusnandar, \& Setyowati, N. 2013. Analisis nilai tambah susu kambing Peranakan Etawah (PE) sebagai bahan baku produk olahan susu kambing Peranakan Etawah di Kabupaten Sleman. AGRISTA. 1:110.

https://jogjaprov.go.id diakses 12 September 2018.

Kotler, P. 2010. Manajemen Pemasaran. Jakarta : PT. Indeks

Moeljanto, Damayanti, R., Bernardinus, T., \& Wiryanta,W. 2002. Khasiat \& Manfaat Susu Kambing : Susu Terbaik dari Hewan Ruminansia. Jakarta: Agromedia Pustaka.

Mulyadi, U.M. 2015. Panduan Terlengkap Beternak Dan Berbisnis
Kambing Etawa \& Kambing Lokal. Yogyakarta: FlashBooks.

Riyanti, B.P. 2003. Kewirausahaan Dari Sudut Pandang Psikologi Kepribadian. Jakarta : PT.Grasindo. Safitri, R. 2012. Produk susu kambing. http://produksusukambingpeternak anberitapeternakanumm.html diakses 12 September 2018

Shane, S., Edwin, A.L., \& Christoper, J.C. 2003. Entrepreneurial Motivation. Human Resource Management Review, 13:257- 279.

Sirait, C.H. 1984. Proses Pengolahan Susu menjadi Yoghurt.WARTAZOA, 1(4).

Sunyoto, D. 2012. Dasar-Dasar Manajemen Pemasaran (Konsep,Strategi, dan Kasus). Yogyakarta: CAPS.

Tampubolon, J., Basita G.S., Margono S.,

Djoko, S., \& Sumardjo. 2006. Pemberdayaan Masyarakat Melalui Pendekatan Kelompok Usaha Bersama (KUBE), Jurnal Penyuluhan, II (2). 